\title{
Effect of Phenformin on Hepatic Balances of Gluconeogenic Substrates in Man
}

\author{
G. Dietze, M. Wicklmayr, H. Mehnert, H. Czempiel, and H. G. Henftling \\ $3^{\text {rd }}$ Medical Department (Metabolism and Endocrinology) and Department of Nuclear Medicine, Schwabing-City Hospital, Munich, FRG
}

Summary. The effect of a five day pretreatment with phenformin $(3 \times 50 \mathrm{mg}$ daily) on hepatic metabolism was studied in six healthy volunteers. Arterial and hepatic venous concentrations of substrates and hepatic blood flow were estimated during a basal period and during a low-dose lactate infusion $\left(0,03 \mathrm{mmol} \cdot \mathrm{kg}^{-1} \cdot \mathrm{min}^{-1}\right)$. The results have been compared with those obtained from untreated normal subjects in a previous study (16). During the baseline period arterial concentration of alanine and the hepatic venous concentration ratios of alanine: pyruvate and $\beta$-hydroxybutyrate: acetoacetate were significantly increased with phenformin treatment, while the balances of carbon dioxide and glucose and the fractional extraction of alanine were decreased compared to the values obtained in untreated subjects. During lactate infusion mean arterial lactate concentration was significantly increased and hepatic lactate extraction was decreased compared to untreated persons under the same conditions. In the phenformin-treated group lactate infusion resulted in hepatic output of pyruvate and the hepatic glucose balance remained unchanged compared to baseline. Since the rate of hepatic blood flow was not increased during lactate infusion a significantly smaller glucose output and lactate uptake was obtained with phenformin. These findings support the present view that the hypoglycaemic effect of biguanides is due, at least in part, to inhibition of hepatic gluconeogenesis.

Key words: Arterial and hepatic venous concentration of substrates, hepatic blood flow, phenformin.

Besides impaired glucose absorption from the gut [1] and accelerated glucose uptake by muscle [2], reduction of hepatic gluconeogenesis has been suggested as an important mechanism explaining the hypogly- caemic effect of the biguanides [3]. Inhibition of gluconeogenesis by biguanides has been observed in liver slices [4] and in the isolated perfused liver [5-8], although rather high concentrations of the drugs were required. Attempts to demonstrate such an effect in man by either measurement of arterial and hepatic venous substrate concentrations after a single oral or parenteral phenformin application $[9,10]$, or by tracer studies using lactate- $\mathrm{C}^{14}$ after several days pretreatment $[11,12]$ have not clearly confirmed the in vitro experiments. It has been shown that biguanide concentrations comparable to those used in in vitro studies $[13,14]$ can be obtained in man only after several days of pretreatment with the drug. We have therefore reinvestigated this problem measuring hepatic metabolite balances by a technique which was successfully applied earlier for study of gluconeogenesis in human liver $[15,16]$.

\section{Material and Methods}

\section{Subjects and Pretreatment}

6 subjects were recruited from medical students of the Munich University School of Medicine. All were informed about the aim and the risks of the study and gave their consent. Their average age was $23.3 \pm 0.6$ years, height $174.8 \pm 2.9 \mathrm{~cm}$ and weight $68.8 \pm$ $2.4 \mathrm{~kg}$ (expected weight range: $64.2-70.2$ [17]). These mean values were not considerably different from those obtained in the untreated controls studied previously (age: $26.5 \pm 0.6$ years; height: $175.3 \pm$ $0.8 \mathrm{~cm}$; weight: $70.9 \pm 1.0 \mathrm{~kg}$ [16]). All subjects were well at the time of study. Liver and renal function tests indicated the absence of gross hepatic and renal disease (mean \pm SEM: GOT $10.0 \pm 0.7 \mathrm{U} / \mathrm{l}$, GPT $9.5 \pm 0.6 \mathrm{U} / \mathrm{l}, \gamma$-globulins $1.06 \pm 0.03 \mathrm{~g} /$ 
$100 \mathrm{ml}$; creatinine: $0.95 \pm 0.05 \mathrm{~g} / 100 \mathrm{ml})^{1}$. Glucose concentrations two hours after $100 \mathrm{~g}$ oral glucose were normal (mean \pm SEM: $5.18 \pm 0.07 \mathrm{mmol} / 1$ ). All subjects were given $50 \mathrm{mg}$ phenformin three times daily for 5 days while continuing their normal intake of food. After an overnight fast each subject received one further dose of $50 \mathrm{mg}$ phenformin one hour prior to the test. None was taking any other drug at the time of study. The protocol of this study was reviewed and approved by the Investigation- and Ethical-Committee of the Sonderforschungsbereich 51 of the Deutsche Forschungsgemeinschaft according to the code of ethics of the World Medical Association [19].

\section{Procedure}

All studies were performed between 8.30 a.m. and $11.30 \mathrm{a} . \mathrm{m}$. in a recumbent position. Under sterile conditions and local anaesthesia a Goodale-Lubin catheter (Type $125 \mathrm{C}$, Size $7 \mathrm{~F}$, US Catheter and Instrument Corporation, Glenforth, USA) was placed from a cubital vein of the left arm into the right hepatic vein, under fluoroscopic control. Thereafter, a Cournand needle (Size PE 160, Kifa, Sweden) was inserted into the right femoral artery. Both were flushed continuously with physiological saline containing small amounts of heparin, at a dose $(0.05 \mathrm{U} / \mathrm{kg} \cdot \mathrm{min})$ which has no significant effect on lipoprotein lipase activity and consequently on free fatty acid levels (20). After an equilibration period of $15 \mathrm{~min}$, arterial and hepatic venous blood samples were collected simultaneously at $10 \mathrm{~min}$ intervals throughout a $30 \mathrm{~min}$ basal period. Sodium lactate ( $150 \mathrm{mmoles} / \mathrm{l})$ was then infused into a cubital vein at a rate of 0.03 mmoles $\cdot \mathrm{kg}^{-1} \cdot \mathrm{min}^{-1}$ and further blood samples were taken at $10 \mathrm{~min}$ intervals for $40 \mathrm{~min}$. Total blood loss was less than $200 \mathrm{ml}$.

During 20 minutes of the basal period and between 20 and 40 minutes during the infusion of lactate, hepatic blood flow (HBF) was measured by a gas exchange technique using ${ }^{133} \mathrm{xenon}$, as described in detail before $[16,21,22]$.

\section{Analysis}

Immediately after sampling, $2 \mathrm{ml}$ of blood were mixed with $6 \mathrm{ml}$ of ice-cold $0.6 \mathrm{~mol} / 1$ perchloric acid and centrifuged at $4^{\circ} \mathrm{C}$. After neutralization with $\mathrm{KHCO}_{3}$ the supernatants were analyzed for pyruvate and acetoacetate within 6 hours. Glucose, lactate,

\footnotetext{
1 Serum glutamate-oxaloacetate-transaminase (GOT), glutamate-pyruvate-transaminase (GPT); determination and normal ranges according to $[18]$
}

glycerol, alanine, free fatty acids and $\beta$-hydroxybutyrate were determined after storage at $-20^{\circ} \mathrm{C}$ overnight. Procedure and precision of the tests has been given elsewhere [16]. From each blood sample determination of the individual substrates was performed at least in duplicate. The basal values represent the mean of 4 determinations obtained at 10 min intervals before the infusion was started. Hepatic uptake of substrates was estimated using those blood samples collected during the measurement of hepatic blood flow [23]. Standard statistical methods were employed using Student's t-test for paired and unpaired samples when applicable [24]. All the mean values are given with the standard error of the mean (SEM).

\section{Materials}

Lactate was used as a sterile aqueous racemate sodium lactate solution containing $150 \mathrm{mmol} / 1$ of sodium D,L-lactate (Department of Pharmacy of Schwabing City Hospital, Munich, FRG). Radioactive ${ }^{133}$ xenon (Radiochemical Centre Amersham, Great Britain) was purchased as a sterile solution of $10 \mathrm{mCi}$ radioactive ${ }^{133}$ xenon in $1 \mathrm{ml}$ sodium chloride $(9 \mathrm{~g} / 1)$. Its specific activity was indicated to be $44.8 \mathrm{Ci} / \mathrm{mmol}$ at a given reference date. Heparin was used as a sterile solution of sodium heparinate containing 5000 USP units/ml (Hoffmann-La-Roche, Grenzach, FRG).

\section{Results}

\section{Arterial Concentrations of Metabolites (Table 1,2)}

Arterial blood concentrations of almost all metabolites were uninfluenced by phenformin as compared to those of untreated volunteers [16] (Table 1). This was also true of the values obtained for carbon dioxide, which were found to be $44.5 \pm 1.9 \mathrm{ml} / 100 \mathrm{ml}$. Arterial concentrations of alanine (Table 2) were elevated ( $\mathrm{p}<0.05$; unpaired $\mathrm{t}$-test) as compared to untreated subjects (controls: $[\mathrm{n}=8], 0.157 \pm$ $0.014 \mathrm{mmol} / \mathrm{l})^{2}$. Hepatic venous concentration ratios of substrates revealed normal lactate: pyruvate ratio, but increased ratios of $\beta$-hydroxybutyrate: acetoacetate and of alanine: pyruvate (Table 2).

During lactate infusion the arterial lactate concentration was doubled within $10 \mathrm{~min}$ and reached almost a steady state after 20 minutes (Table 1 ). The arterial lactate increase in the phenformin pretreated

\footnotetext{
2 These data were derived from [16]
} 
Table 1. Arterial concentrations of metabolites during lactate infusion after phenformin pretreatment

\begin{tabular}{|c|c|c|c|c|c|}
\hline & \multirow[b]{2}{*}{ Basal $^{\mathrm{a}}$} & \multicolumn{4}{|l|}{ Lactate infusion } \\
\hline & & $10 \min$ & $20 \mathrm{~min}$ & $30 \mathrm{~min}$ & $40 \mathrm{~min}$ \\
\hline Glucose & $4.74 \pm 0.13$ & $4.77 \pm 0.16$ & $4.77 \pm 0.13$ & $4.75 \pm 0.11$ & $4.83 \pm 0.12$ \\
\hline Lactate & $0.64 \pm 0.15$ & $1.23 \pm 0.11^{\mathrm{b}, c}$ & $1.47 \pm 0.16^{\mathrm{b}, \mathrm{c}}$ & $1.64 \pm 0.19^{b, c}$ & $1.74 \pm 0.15^{\mathrm{b}, \mathrm{c}}$ \\
\hline Pyruvate & $0.038 \pm 0.01$ & $0.058 \pm 0.01^{\mathrm{b}, \mathrm{c}}$ & $0.070 \pm 0.01^{\mathrm{b}}$ & $0.070 \pm 0.01^{\mathrm{b}}$ & $0.064 \pm 0.01^{b}$ \\
\hline Alanine & $0.237 \pm 0.03^{\mathrm{c}}$ & $0.256 \pm 0.03^{c}$ & $0.262 \pm 0.02^{c}$ & $0.269 \pm 0.03^{\mathfrak{c}}$ & $0.269 \pm 0.03^{c}$ \\
\hline Glycerol & $0.083 \pm 0.01$ & $0.076 \pm 0.02$ & $0.076 \pm 0.02$ & $0.076 \pm 0.02$ & $0.083 \pm 0.01$ \\
\hline Free fatty acids & $0.415 \pm 0.03$ & $0.358 \pm 0.03$ & $0.358 \pm 0.02$ & $0.364 \pm 0.01$ & $0.371 \pm 0.02$ \\
\hline$\beta$-hydroxybutyrate & $0.134 \pm 0.03$ & $0.128 \pm 0.03$ & $0.115 \pm 0.03$ & $0.112 \pm 0.03$ & $0.112 \pm 0.04$ \\
\hline Acetoacetate & $0.089 \pm 0.02$ & $0.077 \pm 0.01$ & $0.064 \pm 0.02$ & $0.070 \pm 0.02$ & $0.064 \pm 0.02$ \\
\hline
\end{tabular}

The values represent the mean \pm SEM of 6 volunteers in $\mathrm{mmol} / \mathrm{l}$

a 4 samples obtained at 10 minute intervals averaged for each subject

b Significant difference to basal ( $\mathrm{p}<0.05$; paired $\mathrm{t}$-test)

c Significant difference to the controls ( $\mathrm{p}<0.05$; unpaired t-test) (see Results)

Table 2. Effect of phenformin pretreatment on splanchnic carbon dioxide balance, fractional extraction of alanine and hepatic venous concentration ratio of lactate: pyruvate, alanine: pyruvate and $\beta$-hydroxybutyrate: acetoacetate

\begin{tabular}{lrrl}
\hline & Control & Phenformin & $\begin{array}{l}\text { Unpaired } \\
\text { t-test }\end{array}$ \\
\hline $\mathrm{n}$ & 10 & 6 & \\
$\begin{array}{l}\text { Carbon dioxide } \\
\quad(\mathrm{ml} / 100 \mathrm{ml})\end{array}$ & $-5.4 \pm 0.6$ & $-3.4 \pm 0.9$ & $\mathrm{p}<0.05$ \\
Alanine (\%) & $26.3 \pm 2.1$ & $15.3 \pm 2.4$ & $\mathrm{p}<0.005$ \\
$\begin{array}{l}\text { Lactate: pyruvate } \\
\text { Alanine: pyruvate }\end{array}$ & $11.7 \pm 1.6$ & $15.9 \pm 2.6$ & $\mathrm{NS}$ \\
$\begin{array}{l}\beta \text {-hydroxybutyrate: } \\
\quad \text { acetoacetate }\end{array}$ & $3.8 \pm 0.5$ & $7.4 \pm 0.8$ & $\mathrm{p}<0.025$ \\
\hline
\end{tabular}

subjects appears to be greater than in control subjects during lactate infusion as observed previously (controls $[\mathrm{n}=8$ ]: Lactate infusion: $10 \mathrm{~min}: 0.90 \pm$ $0.08,20 \mathrm{~min}: 1.16 \pm 0.13,30 \mathrm{~min}: 1.24 \pm 0.10$, $40 \mathrm{~min}: 1.38 \pm 0.10 \mathrm{mmol} / 1$ [18]). The arterial concentration of pyruvate after $10 \mathrm{~min}$ of lactate infusion was significantly higher (Table 1) than in subjects not treated with phenformin (controls: $[n=8]$, lactate infusion: $10 \mathrm{~min}$ : $0.043 \pm 0.003 \mathrm{mmol} / 1$ [16]). The arterial levels of the other substrates were unchanged during lactate infusion (Table 1).

\section{Hepatic Venous Concentrations of Substrates and Hepatic Blood Flow (Table 2, 3)}

Arterial-hepatic venous concentration differences of metabolites were not altered by phenformin pretreatment, with the exception of those of $\mathrm{CO}_{2}$ (Table 2) and glucose which were significantly smaller than observed previously in untreated volunteers under identical conditions $(\mathrm{p}<0.05$, unpaired t-test [Table 3]). The difference of alanine was not increased by the higher alanine concentrations; consequently, fractional alanine extraction became significantly lower than in untreated persons (Table 2). As indicated in Table 3 there was an increase in the arterialhepatic venous difference of glucose during the first 10 min of lactate infusion, after which it returned to the baseline value. Compared with our findings in untreated subjects the glucose differences shown here were significantly smaller during the basal period as well as at any time during lactate infusion (Table 3). This holds also for those of lactate which increased significantly less during lactate infusion. Arterial-hepatic venous differences of pyruvate were significantly decreased during lactate infusion, with negative values after 20 minutes of the infusion. This finding is also distinctly different from previous results on untreated persons during identical lactate infusion (Table 3). During lactate infusion hepatic FFA extraction appeared to be significantly smaller after phenformin pretreatment (mean \pm SEM $[\mathrm{n}=$ 6] basal: $0.102 \pm 0.025 \mathrm{mmol} / 1$; during infusion: $10 \mathrm{~min} 0.071 \pm 0.025,20 \mathrm{~min} 0.070 \pm 0.016$, $30 \min 0.070 \pm 0.012[\mathrm{p}<0.05$; unpaired t-test $]$ and $40 \mathrm{~min} 0.081 \pm 0.025 \mathrm{mmol} / \mathrm{l})$ as compared to the controls (mean \pm SEM $[\mathrm{n}=8$ ] basal: $0.106 \pm$ $0.021 \mathrm{mmol} / \mathrm{l}$; during infusion: $10 \mathrm{~min} 0.098 \pm$ $0.013,20 \min 0.118 \pm 0.02,30 \mathrm{~min} 0.120 \pm 0.022$, $40 \mathrm{~min} 0.126 \pm 0.028 \mathrm{mmol} / 1$ [16]). The rates of hepatic blood flow are shown in Table 3. Phenformin pretreatment had no effect on basal hepatic blood flow and there was no change during lactate infusion, in contrast to normal subjects.

\section{Hepatic Uptake of Substrates}

From the arterial-hepatic venous concentration differences of substrates and the blood flow data (Table 
Table 3. Hepatic blood flow (HBF) and arterial-hepatic venous concentration differences of substrates during lactate infusion in phenformin pretreated subjects $(\mathrm{P})$ as compared to untreated controls $(\mathrm{C})$

\begin{tabular}{|c|c|c|c|c|c|c|}
\hline & \multirow{2}{*}{\multicolumn{2}{|c|}{ Basal $^{\mathbf{a}}$}} & \multicolumn{4}{|l|}{ Lactate infusion } \\
\hline & & & $10 \mathrm{~min}$ & $20 \mathrm{~min}$ & $30 \mathrm{~min}$ & $40 \mathrm{~min}$ \\
\hline $\mathrm{HBF}$ & $\begin{array}{l}\mathbf{P} \\
\mathrm{C}^{\mathrm{d}}\end{array}$ & $\begin{array}{ll}78.0 & \pm 3.2 \\
78.1 & \pm 3.3\end{array}$ & & $\begin{aligned} 78.7 & \pm 2.4^{\mathrm{c}} \\
107.0 & \pm 3.0^{\mathrm{b}}\end{aligned}$ & & \\
\hline Glucose & $\begin{array}{l}\mathrm{P} \\
\mathrm{C}^{\mathrm{d}}\end{array}$ & $\begin{array}{l}-0.28 \pm 0.05^{c} \\
-0.59 \pm 0.07\end{array}$ & $\begin{array}{l}-0.40 \pm 0.04^{\mathrm{b}, \mathrm{c}} \\
-0.96 \pm 0.10^{\mathrm{b}}\end{array}$ & $\begin{array}{l}-0.32 \pm 0.05^{c} \\
-0.84 \pm 0.09^{b}\end{array}$ & $\begin{array}{l}-0.36 \pm 0.04^{\mathrm{c}} \\
-0.84 \pm 0.06^{\mathrm{b}}\end{array}$ & $\begin{array}{l}-0.33 \pm 0.03^{\mathrm{c}} \\
-0.84 \pm 0.10^{\mathrm{b}}\end{array}$ \\
\hline Lactate & $\begin{array}{l}\mathrm{P} \\
\mathrm{C}^{\mathrm{d}}\end{array}$ & $\begin{array}{l}0.15 \pm 0.03 \\
0.11 \pm 0.02\end{array}$ & $\begin{array}{l}0.35 \pm 0.05^{\mathrm{b}} \\
0.37 \pm 0.06^{\mathrm{b}}\end{array}$ & $\begin{array}{l}0.33 \pm 0.07^{\mathrm{b}} \\
0.47 \pm 0.07^{\mathrm{b}}\end{array}$ & $\begin{array}{l}0.33 \pm 0.07^{b, c} \\
0.49 \pm 0.04^{b}\end{array}$ & $\begin{array}{l}0.32 \pm 0.07^{\mathrm{b}, \mathrm{c}} \\
0.55 \pm 0.05^{\mathrm{b}}\end{array}$ \\
\hline Pyruvate & $\begin{array}{l}\mathrm{P} \\
\mathrm{C}^{\mathrm{d}}\end{array}$ & $\begin{array}{l}0.006 \pm 0.002 \\
0.008 \pm 0.002\end{array}$ & $\begin{array}{l}0.006 \pm 0.005 \\
0.008 \pm 0.003\end{array}$ & $\begin{array}{c}-0.006 \pm 0.006^{\mathrm{b}} \\
0.008 \pm 0.004\end{array}$ & $\begin{array}{c}-0.013 \pm 0.006^{b, c} \\
0.008 \pm 0.006\end{array}$ & $\begin{array}{c}-0.013 \pm 0.006^{\mathrm{b}, \mathrm{c}} \\
0.005 \pm 0.006\end{array}$ \\
\hline Alanine & $\stackrel{P}{C^{d}}$ & $\begin{array}{l}0.038 \pm 0.006 \\
0.046 \pm 0.010\end{array}$ & $\begin{array}{l}0.045 \pm 0.012 \\
0.046 \pm 0.008\end{array}$ & $\begin{array}{l}0.038 \pm 0.006 \\
0.044 \pm 0.013\end{array}$ & $\begin{array}{l}0.032 \pm 0.006 \\
0.043 \pm 0.012\end{array}$ & $\begin{array}{l}0.026 \pm 0.012 \\
0.033 \pm 0.010\end{array}$ \\
\hline Glycerol & $\begin{array}{l}\mathrm{P} \\
\mathrm{C}^{\mathrm{d}}\end{array}$ & $\begin{array}{l}0.046 \pm 0.006 \\
0.043 \pm 0.006\end{array}$ & $\begin{array}{l}0.038 \pm 0.006 \\
0.053 \pm 0.009\end{array}$ & $\begin{array}{l}0.038 \pm 0.006 \\
0.050 \pm 0.008\end{array}$ & $\begin{array}{l}0.038 \pm 0.006 \\
0.050 \pm 0.006\end{array}$ & $\begin{array}{l}0.038 \pm 0.006 \\
0.051 \pm 0.007\end{array}$ \\
\hline
\end{tabular}

The values represent the mean $\pm \mathrm{SEM}$ of 6 treated and 8 untreated subjects in $\mathrm{mmol} / \mathrm{l}$. Glycerol data of the controls stem from 6 volunteers

a 4 samples obtained at 10 minute intervals averaged for each subject

b Significant difference to basal. $(\mathrm{p}<0.05$; paired $\mathrm{t}$-test $)$

${ }^{c}$ Significant difference to the controls $(\mathrm{p}<0.05$; unpaired t-test)

d These data were derived from (16)

Tahle 4. Hepatic uptake of substrates during lactate infusion in phenformin-pretreated subjects as compared to untreated controls

\begin{tabular}{|c|c|c|c|c|c|c|c|c|}
\hline & & \multirow{2}{*}{$\begin{array}{l}\text { Glucose } \\
\text { production }\end{array}$} & \multirow{2}{*}{$\begin{array}{l}\text { Calculated } \\
\text { rated of }^{\text {d of }} \\
\text { gluconeogenesis }\end{array}$} & \multicolumn{4}{|c|}{ Precursor uptake } & \multirow{2}{*}{$\begin{array}{l}\text { Calculated } \\
\text { rate }^{d} \text { of } \\
\text { glycogenolysis }\end{array}$} \\
\hline & & & & Lactate & Pyruvate & Alanine & Glycerol & \\
\hline Controls $^{\mathrm{a}}$ & $\begin{array}{l}\text { Basal } \\
\text { Lactate }\end{array}$ & $\begin{array}{l}43.1 \pm 2.9 \\
79.3 \pm 8.3^{b}\end{array}$ & $\begin{array}{l}11.3 \pm 1.6 \\
37.3 \pm 3.3^{b}\end{array}$ & $\begin{array}{l}11.9 \pm 1.1 \\
58.9 \pm 5.8^{b}\end{array}$ & $\begin{array}{l}0.9 \pm 0.2 \\
1.1 \pm 0.2\end{array}$ & $\begin{array}{l}3.1 \pm 1.2 \\
4.6 \pm 1.3\end{array}$ & $\begin{array}{l}3.6 \pm 0.5 \\
5.4 \pm 0.6^{b}\end{array}$ & $\begin{array}{l}31.8 \pm 3.2 \\
42.0 \pm 7.9\end{array}$ \\
\hline Phenformin & $\begin{array}{l}\text { Basal } \\
\text { Lactate }\end{array}$ & $\begin{array}{l}22.5 \pm 3.4^{c} \\
27.0 \pm 3.6^{c}\end{array}$ & $\begin{array}{l}10.0 \pm 1.4 \\
15.7 \pm 2.8^{\mathfrak{c}}\end{array}$ & $\begin{array}{l}12.8 \pm 2.6 \\
25.8 \pm 5.5^{\mathrm{b}, \mathrm{c}}\end{array}$ & $\begin{array}{r}0.9 \pm 0.2 \\
-0.6 \pm 0.4\end{array}$ & $\begin{array}{l}3.1 \pm 0.3 \\
3.1 \pm 0.5\end{array}$ & $\begin{array}{l}3.7 \pm 0.4 \\
3.1 \pm 0.1^{\mathrm{c}}\end{array}$ & $\begin{array}{l}13.8 \pm 2.9^{c} \\
11.2 \pm 2.7^{\mathrm{c}}\end{array}$ \\
\hline
\end{tabular}

The data tepresent the mean $\pm \mathrm{SEM}$ in $\mu \mathrm{mol} \cdot 100 \mathrm{~g}$ liver $\mathrm{wt}^{-1} \mathrm{~min}^{-1}$ of 6 subjects obtained at 30 min during lactate infusion

a These data were derived from $(16)$

b Significant difference to basal $(\mathrm{p}<0.05$; paired $\mathrm{t}$-test)

c Significant difference to the corresponding values of the controls $(\mathrm{p}<0.05$; unpaired $t$-test)

$d$ These values are indicated in glucose equivalents and hepatic aminoacid uptake was estimated as twice that of alanine (40)

3) a significantly smaller basal hepatic glucose output was calculated after phenformin treatment $(\mathrm{p}<0.05$; unpaired t-test) (Table 4). Thereby, the basal precursor uptake was not diminished. In untreated healthy subjects lactate infusion led to a near doubling of hepatic glucose production and to a 5-fold increase of lactate uptake (Table 4). There was no significant alteration of glucose output and only slight acceleration of lactate uptake after pretreatment with phenformin. Furthermore, lactate infusion did not stimulate glycerol uptake and, in striking contrast to the controls, there was a release of pyruvate from the liver (Table 4).

Corresponding to the smaller arterial-hepatic venous difference of FFA and the deficient blood flow response during lactate infusion hepatic FFA uptake was considerably lower after phenformin pretreatment (mean \pm SEM $[\mathbf{n}=5]$ basal: $7.78 \pm 1.2$, lactate: $6.06 \pm 2.4 \mu \mathrm{mol} / 100 \mathrm{~g} \cdot \min [\mathrm{p}<0.05$; unpaired t-test]) as compared to the controls, who showed significant increase during lactate infusion (mean \pm SEM $[\mathrm{n}=8$ ]; basal: $8.7 \pm 1.6$, lactate: 12.6 $\pm 2.2 \mu \mathrm{mol} / 100 \mathrm{~g} \cdot \min [\mathrm{p}<0.05 ;$ paired t-test $])$.

\section{Discussion}

The aim of this work was to study the effect of therapeutic doses of phenformin on lactate gluconeogenesis in healthy subjects. Data on gluconeogenesis obtained in healthy subjects without phenformin treatment, but under otherwise identical condi- 
tions [16], were used for comparison. It is suggested that the amount and method of phenformin administration yields biguanide concentrations in the liver comparable to those proven effective in the isolated perfused organ $[13,14]$. In previous studies we had shown that substrate concentrations were essentially identical in arterial and portal venous blood after an overnight fast and during lactate infusion [16]. On the assumption that this holds true also during phenformin treatment it appears justified to interpret the present substrate balance data derived from arterialhepatic venous concentration differences as a reflection of the metabolic performance of the liver.

The reduced hepatic glucose production during the basal period after phenformin (Table 4) is most probably explained by a smaller rate of glucose output deriving from glycogen, either due to altered activity of glycogenolytic enzymes and/or to depleted glycogen stores. There is support for the latter possibility $[3,25]$. A depletion of the hepatic glycogen stores could be due to a slower rate of gluconeogenesis $[5,8]$ and/or an accelerated rate of glycolysis induced by an impaired cellular respiration during biguanide treatment [26-29]. From numerous in vitro experiments there is evidence that biguanides inhibit gluconeogenesis by lowering the energy production of the liver cell through interference with oxidation phosphorylation or with mitochondrial respiration, as indicated by reduced hepatic oxygen consumption and $\mathrm{CO}_{2}$ production [5, 8,26-29]. Our finding of an increase of the hepatic venous concentration ratios of $\beta$-hydroxybutyrate: acetoacetate and alanine: pyruvate, of a smaller $\mathrm{CO}_{2}$ balance (Table 2) and a reduced percentual alanine extraction, with a concomitant rise of arterial alanine concentrations, is consistent with this hypothesis $[6,30,31]$. It seems noteworthy that in spite of the reduction of basal hepatic glucose output, the arterial glucose concentration was not significantly different from that in untreated persons. This finding is in line with the present view that biguanides lower blood sugar levels in diabetics but not in healthy subjects [32]. This phenomenon may be explained by our recent observation that, in contrast to the effect in diabetic subjects [2], glucose uptake by muscle in the forearm of healthy volunteers was significantly reduced by phenformin under identical conditions [33].

Assuming impaired gluconeogenesis and cellular respiration to be responsible for the altered glucose output already seen during the basal period impairment should become more obvious under conditions of increased biosynthetic activity, e.g. during the accelerated formation of glucose from lactate. In our studies, after pretreatment with phenformin, the human liver was no longer capable of accelerating its rate of glucose formation from lactate when arterial lactate concentration was increased (Table 4). Even if hepatic blood flow were increased to a similar extent during lactate infusion as was found in the untreated controls (Table 3), the smaller arterialhepatic venous concentration difference of lactate would have yielded a significantly smaller hepatic rate of uptake. This was also true of hepatic glucose production, which was not altered during lactate infusion, as compared to the basal period (Table 4). In the isolated perfused liver $(34,35)$ and in the dog in vivo [36] the higher energy demand for accelerated gluconeogenesis is met by enhanced oxidation of long chain fatty acids, with increases of corresponding $\mathrm{CO}_{2}$ production and oxygen consumption. There was no significant increase of hepatic FFA uptake in the pretreated subjects in contrast to what had been observed in the controls (see Results). The striking pyruvate production occurring under phenformin treatment during lactate infusion may also be explained as a consequence of insufficient energy supply, since ATP-dependent phosphorylation reactions were found to be impaired in the phenformin treated perfused rat liver $[6,8]$. Although the present findings were obtained in healthy subjects it is possible that phenformin acts on liver metabolism in a similar manner in diabetic patients. If so, the inhibition of hepatic gluconeogenesis from lactate, in addition to the reduction of glucose absorption [1] and the stimulation of glucose uptake in muscle [2] may contribute to the blood sugar lowering effect of the biguanides in maturity onset diabetics. Furthermore, the impaired hepatic lactate uptake due to phenformin may at least partly explain the unfavourable side effect of biguanide therapy, namely the occurrence of fatal lactic acidosis [37-39]. Corresponding to this view, the biguanides' blood sugar lowering effect cannot entirely be disconnected with their suppressive action on hepatic lactate utilization.

Acknowledgement. We are grateful to Prof. Dr. O. H. Wieland for advice and critical review of the manuscript, to Dr. E.Jörn for statistical mathematics and to the Leibnitz Rechenzentrum, Bavarian Academy of Sciences for good cooperation. We are indebted to Ing. E. A. Bauer, Miss E. Müller, A. Bammert, Miss E. Maerker, A. Kirschner and J. Strigel for expert technical assistance. This work was supported by a grant from the Deutsche Forschungsgemeinschaft, SFB 51, Munich.

\section{References}

1. Czyzyk, A., Lawecki, J., Sadowski, J., Panikowska, J., Szcepanik, Z.: Effect of biguanides on intestinal absorption of glucose. Diabetes 17, 492-498 (1968)

2. Butterfield, W.J.H., Whichelow, M.J.: Effect of diet, sulphonylureas and phenformin on peripheral glucose uptake in diabetes and obesity. Lancet 1968 II, 785-793 
3. Tyberghein, J.M., Williams, R.H.: Metabolic effects of phenethylbiguanide, a new hypoglycemic compound. Proc. Soc. Exp. Biol. Med. 96, 29-34 (1957)

4. Patrick, S.J.: Effect of phenformin and hypoglycin on gluconeogenesis of rat tissues. Can. J. Biochem. 44, 27-33 (1966)

5. Altschuld, R.A., Krüger, F.A.: Inhibition of hepatic gluconeogenesis in guinea pig by phenformin. Ann. N.Y. Acad. Sci. 148, 612-622 (1968)

6. Toews, C. J., Kyner, J.L., Connon, J. J.: The effect of phenformin on gluconeogenesis in isolated perfused rat liver. Diabetes 19, $368(1970)$

7. Creutzfeldt, W., Willms, B., Caspary, W.: The mechanism of action of the blood glucose lowering biguanides. In: R. R. Rodriguez, J.Vallance-Owen (Eds.): Diabetes, (Proc. $7^{\text {th }}$ Congr. Int. Diab. Fed.), pp. 708-719. Amsterdam: Excerpta Medica 1971

8. Haeckel, R., Haeckel, H.: Inhibition of gluconeogenesis from lactate by phenethyl-biguanide in the perfused guinea pig liver. Diabetologia 8, 117-124 (1972)

9. Tranquada, R.E., Kleemann, C., Brown, J.: Some effects of phenethylbiguanide on human hepatic metabolism as measured by hepatic vein catheterization. Diabetes 9, 207-214 (1960)

10. Beringer, A., Hupka, K., Mosslacher, K., Moser, K., Wenger, R.: Zur Beeinflussung des menschlichen Diabetes mit Insulin, blutzuckersenkenden Sulfonamiden sowie Biguaniden. Wien Med. Wochenschr. 108, 639-644 (1958)

11. Searle, G.L., Cavalieri, R. R.: Glucose kinetics before and after phenformin in the human subject. Ann. N. Y. Acad. Sci. 148, 734-742 (1968)

12. Kreisberg, R.A.: Glucose metabolism in normal and obese subjects. Effect of phenformin. Diabetes 17, 481-487 (1968)

13. Wick, A. N., Stewart, Ch. J., Serif, G. S.: Tissue distribution of $\mathrm{C}^{14}$-labeled betaphenethyl-biguanide. Diabetes 9, 163-167 (1960)

14. Beckmann, R.: Resorption, Verteilung im Gewebe und Ausscheidung von 1-Butyl-biguanid ${ }^{14} \mathrm{C}$-hydrochlorid. Drug Res. 15, 761-764 (1965)

15. Wahren, J., Felig, P., Ahlberg, G., Jorfeldt, L.: Glucose metabolism during leg exercise in man. J. Clin. Invest. 50, 2715-2725 (1971)

16. Dietze, G., Wicklmayr, M., Hepp, K.D., Bogner, W., Mehnert, H., Czempiel, H., Henftling, H.G.: On gluconeogenesis of human liver. Accelerated hepatic glucose formation induced by increased precursor supply. Diabetologia 12, 555-561 (1976)

17. Statist. Bull. Metrop. Life Insur. Co.: 40, Nov,-Dec. (1959)

18. Empfehlungen der Deutschen Gesellschaft für klinische Chemie. J. Clin. Chem. Clin. Biochem. 14, 182-192 (1972)

19. World Medical Association Declaration of Helsinki Br. Med. J. 1964 II, 177-180

20. Boberg, J.: Heparin-released blood plasma lipoprotein lipase activity in patients with hyperlipoproteinemia. Acta Med. Scand. 191, 97-105 (1972)

21. Schmitz-Feuerhake, J., Tägder, K., Fröhlich, H., Pixberg, H. U., Haubold, E.: Die Bestimmung der spezifischen Durchblutung von Leber, Milz, und Niere durch Inhalation von radioaktivem Xenon. In: P. M van Vaerenbergh, H. W. Pabst, G.Hör (Eds.): Nuklearmedizin. ( $9^{\text {th }}$ Ann. Meet. Soc. Nucl. Med., Antwerpen 1971), pp. 264-268. New York: Schattauer Verlag 1973

22. Dietze, G., Wicklmayr, M., Czempiel, H., Henftling, H. G., Mehnert, H.: On the analysis of the hepatic-venous ${ }^{133}$ xenonclearance after the application of the gas by inhalation. Klin. Wochenschr. 53, 638-640 (1975)
23. Zierler, K. L.: Theory of the use of arteriovenous concentration differences for measuring metabolism in steady and nonsteady states. J. Clin. Invest. 40, 2111-2131 (1961)

24. Snedecor, G. W., Cochran, W. G.: Statistical methods, $6^{\text {th }}$ edition. Ames, Iowa: Iowa State University Press 1967

25. Ungar, G., Freedman, L., Shapiro, S.L.: Pharmacological studies on a new hypoglycemic drug. Proc. Soc. Exp. Biol. Med. 95, 190-194 (1957)

26. Hollunger, G.: Guanidines and oxidative phosphorylation. Acta Pharmacol. Toxicol. (Kbh.) 11 (Suppl. 1), 1-84 (1955)

27. Schäfer, G.: Some new aspects on the interaction of hypoglycemia-producing biguanides with biological membranes. Biochem. Pharmacol. 25, 2015-2024 (1976)

28. Wick, A.N., Larson, E., Serif, G.S.: A site of action of phenethylbiguanide, a hypoglycemic compound. J. Biol. Chem. 233, 292-296 (1958)

29. Steiner, D.F., Williams, R.H.: Respiratory inhibition and hypoglycemia by biguanides and decamethylene-diguanide. Biochim. Biophys. Acta 93, 279-283 (1964)

30. Bücher, Th., Klingenberg, M.: Wege des Wasserstoffs in der lebendigen Organisation. Angew. Chem. (Engl.) 70, 552-570 (1958)

31. Marliss, E.B., Aoki, T.T., Toews, C.J., Felig, P., Connon, J.J., Kyner, J., Huckabee, W.E., Cahill, G.F.: Amino acid metabolism in lactic acidosis. J. A. M. A. 52, 474-481 (1972)

32. Fajans, S.S., Moorhouse, J. A., Doorenbos, H., Louis, L. H., Conn, J. W.: Metabolic effects of phenethylbiguanide in normal subjects and in diabetic patients. Diabetes 9, 194-201 (1960)

33. Dietze, G., Wicklmayr, M., Braun, S., Hepp, K. D., Mehnert, H.: Untersuchungen zur Wirkung von Biguaniden am Gesunden. Die Glukoseutilisation des Muskels unter dem Einfluß von Phenformin. Verh. Dtsch. Ges. Inn. Med. 80, 1283-1286 (1974)

34. Schimassek, H.: Metabolite des Kohlenhydratstoffwechsels der isoliert perfundierten Rattenleber. Biochem. Z. 336, 460-465 (1963)

35. Hems, R., Ross, B.D., Berry, M.N., Krebs, H.A.: Gluconeogenesis in the perfused rat liver. Biochem. J. 101, 284-292 (1966)

36. Kramer, K., Driessen, G., Brechtelsbauer, H.: Lactate elimination and $\mathrm{O}_{2}$-consumption of the liver in narcoticized dogs. Pfluegers Arch. 330, 195-202 (1971)

37. Tranquada, R.E., Bernstein, S., Martin, H.E.: Irreversible lactic acidosis associated with phenformin therapy. J. A. M. A. 184, 43-47 (1963)

38. Buess, H. J., Mihatsch, M. J., Wunderlich, P., Berger, W.: Laktatazidose beim Diabetes mellitus. Schweiz. Rundschau Med. 65, 406-410 (1976)

39. Wittmann, P., Haslbeck, M., Bachmann, W., Mehnert, H.: Lactic acidosis in diabetics on biguanides. Dtsch. Med. Wochenschr. 102, 5-10 (1977)

40. Owen, O.E., Felig, P., Morgan, A.P., Wahren, J., Cahill, G. F., Jr.: Liver and kidney metabolism during prolonged starvation. J. Clin. Invest. 48, 574-583 (1969)

Received: July 28, 1977, and in revised form: November 30, 1977

Dr. G. Dietze

$3^{\text {rd }}$ Medical Department (Metabolism and Endocrinology)

Schwabing City Hospital

Kölner Platz 1

D-8000 Munich 40

Federal Republic of Germany 